ISSN No. 0974-035X

An indexed refereed \& peer-reviewed journal of higher education

Towards Excellence

UGC-HUMAN RESOURCE DEVELOPMENT CENTRE

Gujarat University, Ahmedabad-380009, Gujarat, India

\title{
STUDENTS PERCEPTION'S TOWARDS ONLINE TEACHING: AN EMPIRICAL STUDY IN BERHAMPUR UNIVERSITY
}

\section{Dr Bharat Kumar Lakra}

\begin{abstract}
In the Coronavirus disease -19 (COVID-19) response, all the educational institutions have been compulsory to move all teaching and learning activities online at very short time notice by the University Grand Commission (UGC). Consequently, all classes, simulations, practicums, viva-voces, and valuation, etc., were adapted for the online setting. Online education has been at the forefront of discussions as a new and viable option for learning opportunities in higher education. Academic institutions continue to see remarkable growth of online education during COVID-19. Due to the pandemic situation, UGC has instruction with 40 per cent of online learning. Hence educational institutions have been implementing online classes. The article investigates to identify the factors which students perceive significant influence towards online class. From a student perception, there has been adaptation and the prospect to advance new skills, possibly providing online teaching via elearning or virtual learning. Further, this study sought to provide an investigation of online teaching in University with an intention on how the teaching and learning interaction will affect students 'perceptions relating to their online class preparedness and experiences. The results revealed from descriptive statistics, correlation, and regression analysis that students reported a moderate relationship between the extracted factor scores and overall satisfaction of online teaching. The findings of four factors that affect the students' views about online teaching characteristics instruction seen that student perceptions about online teaching are positively affected by "Perceived Usefulness" of online teaching. The second most important factor is student supportiveness, followed by faculty responsiveness and perceived flexibility. Further, Multiple Regression Analysis has been analysed to inspect the relationship between the various online teaching characteristics and the overall satisfaction from online teaching. Thus, this study may be helpful to teachers in constructing proper pedagogical techniques
\end{abstract}


Towards Excellence: An Indexed, Refereed \& Peer Reviewed Journal of Higher Education /

Dr. Bharat Kumar Lakra / Page 196-213

which can be suitable and beneficial for learning, understanding and application of the online teaching-learning process.

Keywords: Online teaching, Student perceptions, Instructional strategy, COVID-19, Satisfaction

\section{Introduction}

In response to the Coronavirus disease-19 (COVID-19) pandemic situation, UGC has instruction with 40 per cent of online teaching and learning. Hence educational institutions have been implementing online classes. In the rising infection about the current COVID-19 pandemic, most of all universities around the world have either postponed or cancelled all campus events such as classes, workshops, conferences, sports and other activities. Universities have moved quickly to transition various courses and programs from off-line to online delivery mode.

Again, the modern advances in information technologies and the increasing interest of a large number of persons to get higher education have led to the rapid evolution of online education. Teaching online is dissimilar with traditional classroom teaching (Capra, 2011). Once teaching online, teachers have to play a different role from their traditional one (Sammons, 2003). The online instructional strategies that generate and inspire learner's inquiry to grow learning experience of the subject matter, which critical reflection of the learning experience was originated effective in online teaching (Keeton, 2004). For active online education, teachers should be ready to use a variety of instructional strategies (Cuthrell and Lyon, 2007; Dixson, 2010) to adoptive student participation, inspire intellectual growth, and build rapport with students (Brinthaupt et al., 2011). The opinions of Brinthaupt et al. (2011) and Keeton (2004) towards online teaching showing the need for paying consideration to design and delivery of online classes with the up-to-date information technology for creating an instructional setting resembling a classroom situation. COVID-19 and the shift to online learning have created new challenges and opportunities among the students.

\section{Literature reviews}

Online teaching is speedily developing in the realm of higher education and gaining adhesion on a global level. The use of online learning technology is infusing higher education at a rapid rate, with over $80 \%$ of teachers using online technology in some form (Allen \& 
Seamen, 2013). The role of the e-learning and teaching systems in higher education is becoming more and more active. The number of teachers that are currently using e-learning and teaching in their professional activities has been increasing in the last years (Moise et al., 2012). Teachers capability to design high-quality online instructional plans and enable student learning were acknowledged as the most important skills for the online teacher (Kim and Bonk, 2006). When instructors redesign their face-to-face classes for online delivery, the major question they encounter is what instructional activities are effective in teaching online. For instance, Hutton (1999) informed that clearly specified learning goals, threaded discussions, and complementary use of technologies such as videos and audios are necessary instructional activities for effective online teaching. The literature reveals various perspectives regarding appropriate instructional strategies for online courses. For instance, Hutton (1999) reported that clearly specified learning goals, threaded discussions, and complementary use of technologies such as videos and audios are necessary instructional activities for successful online teaching. Salas- Morera et al. (2012) revealed that students like quizzes and they had a helpful effect on student learning. If student preferred online instructional activities and their perceived effectiveness are identified, teachers will be able to design online classes to meet student expectations. Ruth and Conners (2012) discussed the results of their study listing two advantages to students taking courses online. The first advantage of online or asynchronous courses is that it offers flexibility in scheduling coursework around family, work, or other commitments as well as flexibility in taking courses from remote locations. Graduate students pointed to the development of the online community and the opportunity to have a deeper understanding of the course material as positive aspects of online learning (Carlson \& Jesseman, 2011). With evolving technologies, numerous resources exist for faculty who teach online to creatively engage students and effectively build connections. Several other scholarly papers studied the importance of faculty presence and their effect on online student success and satisfaction. In understanding student needs and preferences, studies show that faculty-student interaction and online relationship play a significant role in student achievement and learning, and successful course completion. Morris and Finnegan (2008) posited that faculty needs to assume a managerial role and pedagogical role in guiding students in navigating course content and layout as well as providing feedback on student participation. Although much discussion has ensued on the advantages of online education with regards to flexibility and convenience with time, schedule, and cost, online instruction also allows students to absorb material at their own pace within a predetermined time frame (Perry \& Pilati, 2011). Further, from a curriculum 
viewpoint, it is crucial to review how online learning aligns with the pedagogy of the teaching program, and the understanding and well-being of the students. Students in the current online environment have spoken of challenges with self-regulation skills such as time management and motivation, and that they feel isolated and distant from the learning. This experience brings into line with previous findings that student encounters in the online environment of blending learning include: self-regulation; technological literacy and competency; student isolation; technical sufficiency; and technological complexity (Rasheed, Kamsin, \& Abdullah, 2020). Therefore, it is needed to keep the focus on the students, their experiences, and their learning. Smith and Hill (2018) highlight that blended learning is only useful when the purpose of the online content is clear with explicit links made to the face-to-face classes off-line classes.

The purpose of this study was to contribute to this knowledge gap. This study provides added insight into the need for faculty's presence to guide students and anticipate their needs from a pedagogical and technological standpoint.

\section{Research Objectives}

1. To investigate the perceptions of university students regarding online teaching.

2. To identify the key factors that influence the students' views towards online teaching.

3. To establish the relationship between the factors reflecting students views towards online teaching and overall satisfaction levels of the students.

\section{Research Methodology}

\section{Instrumentation}

The survey instrument designed for this study, a structured questionnaire having 26 Likert Scale statements along with basic and demographic information was collected through e-mail and WhatsApp groups for primary data collection. The responses were coded and recoded in SPSS software for data analysis. The scale used to record students' attitudes toward online teaching classes contained five items related to online learning with a 5-point Likert scale $(1=$ Strongly Disagree, $5=$ Strongly Agree). Students' responses to five items were aggregated to get the overall attitude score. A panel of educators reviewed the survey instrument to establish instrument validity. Internal consistency was tested to establish the reliability of the instrument.

\section{Population and Study sample}


Post-graduate students enrolled in the Berhampur University at South Odisha State University in 2019-2020 academic year comprised the study population. There were 1056 students in the population frame. The researcher drew a random sample of 226 students out of this student's population.

\section{Data collection}

The online survey was administered through the questionnaire, and the survey link was sent with an e-mail and WhatsApp. Students selected for the study were given two weeks to respond to the survey request from $3^{\text {rd }}$ to $17^{\text {th }}$ November 2020.

\section{Data Analysis and Interpretation}

All the questionnaires were coded, and data was verified for data analysis. The data were cleaned, and the tables were prepared, and descriptive studies were derived. Frequencies and percentage were calculated. For the reliability of the instrument, Cronbach's Alpha was calculated for the scale items. Cronbach's alpha was 0.936, which suggests fair and acceptable reliability. Factor analysis was applied to find out the factors reflecting the student's perception regarding online teaching. In order to find out the most causal factor affecting overall satisfaction of online teaching, multiple regression analysis was done between the overall satisfaction and extracted factors scores as independent variables.

The demographic profile of the respondents is as follows:

Table-1: Demographic Details $(n=266)$

\begin{tabular}{|c|l|l|l|}
\hline Sr. & Demographics & Frequency & Percentage \\
\hline 1 & $\begin{array}{l}\text { Age group } \\
18-24 \text { years } \\
25-29 \text { years } \\
30 \text { and above }\end{array}$ & 244 & 91.7 \\
& $\begin{array}{l}\text { No. } \\
2\end{array}$ & $\begin{array}{l}\text { Gender } \\
\text { Male }\end{array}$ & 6.8 \\
\hline & Female & 117 & 1.5 \\
\hline
\end{tabular}


Towards Excellence: An Indexed, Refereed \& Peer Reviewed Journal of Higher Education / Dr. Bharat Kumar Lakra / Page 196-213

\begin{tabular}{|c|l|l|l|}
\hline 3 & The subject of Online Course & & \\
& Arts \& Humanities & 98 & 36.8 \\
& Commerce \& Management & 36 & 13.5 \\
& Science & 132 & 49.6 \\
\cline { 2 - 4 } & Enrolment Status & & \\
& Full-time & 266 & 100 \\
\hline 5 & Part-time & Nil & \\
& Place of Living & 58 & 21.8 \\
& Urban & 79 & 29.7 \\
& Semi-Urban & 129 & 48.5 \\
& Rural & & 82.3 \\
\hline 6 & Online Class Enter through & & 13.5 \\
& Android Mobile & 219 & 4.1 \\
\hline & Laptop & 36 & \\
& Desktop & 11 & \\
\hline
\end{tabular}

From the above table-1, it is shown that 266 respondents were responded to the survey. Out of the 266 respondents, most were between the age group 18- 24 years (91.7\%), female (56\%), with the highest level of online education was science $(49.6 \%)$ with full - time enrolment status was $100 \%$. Most of the respondents were living in the rural area (48\%) and with the highest number of online classes were enter through Android Mobiles (82.3\%).

Table-2 below indicates the descriptive analysis of the scores obtained of 266 respondents on 26 items under study:

Table-2: Descriptive Statistics $(n=266)$

\begin{tabular}{|c|c|c|c|c|}
\hline Sr. No. & Items & Mean & $\begin{array}{c}\text { Std. } \\
\text { Deviation }\end{array}$ & $\begin{array}{c}\text { Co- } \\
\text { efficient } \\
\text { of } \\
\text { Variation }\end{array}$ \\
\hline 1 & I find online learning classes are useful & 3.61 & 1.104 & 30.564 \\
\hline 2 & $\begin{array}{l}\text { Using online learning is easier to complete } \\
\text { my tasks }\end{array}$ & 3.43 & 1.114 & 32.505 \\
\hline
\end{tabular}


Towards Excellence: An Indexed, Refereed \& Peer Reviewed Journal of Higher Education /

Dr. Bharat Kumar Lakra / Page 196-213

\begin{tabular}{|c|c|c|c|c|}
\hline 3 & Online material assists my learning & 3.61 & 0.954 & 26.442 \\
\hline 4 & $\begin{array}{l}\text { The online learning system can improve } \\
\text { teaching \& learning process }\end{array}$ & 3.42 & 1.157 & 33.795 \\
\hline 5 & $\begin{array}{l}\text { The online learning system can improve my } \\
\text { academic performance }\end{array}$ & 3.30 & 1.187 & 36.010 \\
\hline 6 & I find the online learning system easy to use & 3.71 & 1.123 & 30.239 \\
\hline 7 & Online learning is user-friendly & 3.62 & 1.120 & 30.904 \\
\hline 8 & I intend to do fully online class & 3.34 & 1.178 & 35.278 \\
\hline 9 & Online classes are easier & 3.48 & 1.096 & 31.455 \\
\hline 10 & $\begin{array}{l}\text { Online discussion facilitates my achievement } \\
\text { of the objectives of the course }\end{array}$ & 3.39 & 1.138 & 33.567 \\
\hline 11 & $\begin{array}{l}\text { Multimedia lectures facilitate my } \\
\text { achievement of the objectives of the course }\end{array}$ & 3.51 & 1.010 & 28.772 \\
\hline 12 & $\begin{array}{l}\text { Web conferencing facilitates my } \\
\text { achievement of the course objectives }\end{array}$ & 3.44 & 1.045 & 30.414 \\
\hline 13 & $\begin{array}{l}\text { Web Chatting sessions are useful for clarity } \\
\text { of the subjects }\end{array}$ & 3.29 & 1.090 & 33.129 \\
\hline 14 & $\begin{array}{l}\text { Online feedback provided is useful for topic } \\
\text { understanding }\end{array}$ & 3.60 & 0.994 & 27.596 \\
\hline 15 & $\begin{array}{l}\text { The teacher responds promptly to e-mails } \\
\text { and other communications }\end{array}$ & 3.90 & 0.931 & 23.846 \\
\hline 16 & $\begin{array}{l}\text { The teacher provides useful comments on } \\
\text { my tasks by online }\end{array}$ & 3.83 & 0.918 & 23.967 \\
\hline 17 & $\begin{array}{l}\text { Online classes offer more flexibility in } \\
\text { managing my study time }\end{array}$ & 3.68 & 1.043 & 28.364 \\
\hline 18 & $\begin{array}{l}\text { Online classes offer more flexibility in } \\
\text { organizing my study materials }\end{array}$ & 3.46 & 1.099 & 31.774 \\
\hline 19 & $\begin{array}{l}\text { Online classes offer more flexibility in terms } \\
\text { of deadlines }\end{array}$ & 3.54 & 1.053 & 29.745 \\
\hline 20 & $\begin{array}{l}\text { Online classes are easy to fit into my } \\
\text { schedule }\end{array}$ & 3.45 & 1.159 & 33.546 \\
\hline 21 & $\begin{array}{l}\text { I think I could be participative more in-class } \\
\text { discussion in an online class }\end{array}$ & 3.45 & 1.122 & 32.524 \\
\hline
\end{tabular}


Towards Excellence: An Indexed, Refereed \& Peer Reviewed Journal of Higher Education /

Dr. Bharat Kumar Lakra / Page 196-213

\begin{tabular}{|c|l|l|l|l|}
\hline 22 & $\begin{array}{l}\text { I think I would understand more in the } \\
\text { online class }\end{array}$ & 3.31 & 1.193 & 36.017 \\
\hline 23 & $\begin{array}{l}\text { I think I would engage more in the online } \\
\text { class }\end{array}$ & 3.34 & 1.203 & 36.038 \\
\hline 24 & $\begin{array}{l}\text { I think I would gain more knowledge in an } \\
\text { online class }\end{array}$ & 3.25 & 1.213 & 37.312 \\
\hline 25 & $\begin{array}{l}\text { I think online classes have easier } \\
\text { assignments }\end{array}$ & 3.50 & 1.093 & 31.191 \\
\hline 26 & I think online classes are easier to follow & 3.63 & 1.060 & 29.195 \\
\hline
\end{tabular}

The highest means score correspondents to items no.17, which shows that Online classes offer more flexibility in managing my study time. The least mean score is item no. 24, which implies that I think I would gain more knowledge in an online class. The Coefficient of Variation of item no. 3 is the least one which indicates that the responses for variable no. 3 are most consistent. The Coefficient of Variation of item 23 is the highest one which indicates that the responses for variable no.23 are most inconsistent.

Factor analysis was applied to identify the factors that reflect the student's perceptions of online teaching. In order to test the data appropriateness for factor analysis "KMO and Bartlett's test" was carried out in the Table-3 as below:

Table-3: KMO and Bartlett's Test

\begin{tabular}{|l|l|l|}
\hline \multicolumn{3}{|c|}{ KMO and Bartlett's Test } \\
\hline \multicolumn{2}{|c|}{ Kaiser-Meyer-Olkin Measure of Sampling Adequacy } & 0.947 \\
\hline Bartlett's Test of Sphericity & Approx. Chi-Square & 2999.946 \\
\cline { 2 - 3 } & df & 325 \\
\cline { 2 - 3 } & Sig. & 0 \\
\hline
\end{tabular}

The value of KMO is 0.947 ; hence the data is suitable for Factor analysis. In order to test the null hypothesis, Bartlett's Test of Sphericity was applied and disclosed that the significant value was 0.000 which is less than the 0.05 this testified that the sample was appropriate for factor analysis. It may be well-known here that the sample size of 266, which is more than ten times the number of variables twenty-six (26). All these validate the use of Factor Analysis for this study. 
Towards Excellence: An Indexed, Refereed \& Peer Reviewed Journal of Higher Education / Dr. Bharat Kumar Lakra / Page 196-213

In order to test the following hypothesis:

H0: There is no significant relationship between the variables in the population.

H1: There is a significant relationship between the variable in the population.

In the above table-3, Bartlett's Test of Sphericity was applied, which showed that the significant value was 0.000 which is less than the 0.05 and hence the null hypothesis(H0) was rejected, approx. Chi-square value is 2999.946, which is very large and hence it can be concluded that there is a significant relationship between the variables in the population.

Table-4: Factor Analysis

\begin{tabular}{|c|c|c|c|c|c|c|c|c|c|}
\hline \multicolumn{10}{|c|}{ Total Variance Explained } \\
\hline \multirow[t]{2}{*}{ Component } & \multicolumn{3}{|c|}{ Initial Eigenvalues } & \multicolumn{3}{|c|}{$\begin{array}{l}\text { Extraction Sums of Squared } \\
\text { Loadings }\end{array}$} & \multicolumn{3}{|c|}{$\begin{array}{l}\text { Rotation Sums of } \\
\text { Squared Loadings }\end{array}$} \\
\hline & Total & $\begin{array}{l}\% \text { of } \\
\text { Varia- } \\
\text { nce }\end{array}$ & $\begin{array}{l}\text { Cumul- } \\
\text { ative } \\
\%\end{array}$ & Total & $\begin{array}{l}\% \text { of } \\
\text { Varian- } \\
\text { ce }\end{array}$ & $\begin{array}{l}\text { Cumulative } \\
\%\end{array}$ & Total & $\begin{array}{l}\text { \% of } \\
\text { Varian- } \\
\text { ce }\end{array}$ & $\begin{array}{l}\text { Cumul- } \\
\text { ative } \\
\%\end{array}$ \\
\hline 1 & 9.941 & 38.230 & 38.233 & 9.941 & 38.233 & 38.233 & 5.623 & 21.626 & 21.626 \\
\hline 2 & 1.612 & 6.200 & 44.433 & 1.612 & 6.200 & 44.433 & 4.043 & 15.550 & 37.176 \\
\hline 3 & 1.156 & 4.446 & 48.879 & 1.156 & 4.446 & 48.879 & 2.242 & 8.624 & 45.800 \\
\hline 4 & 1.041 & 4.006 & 52.884 & 1.041 & 4.006 & 52.884 & 1.842 & 7.085 & 52.884 \\
\hline 5 & 0.995 & 3.828 & 56.712 & & & & & & \\
\hline 6 & 0.954 & 3.670 & 60.382 & & & & & & \\
\hline 7 & 0.837 & 3.219 & 63.602 & & & & & & \\
\hline 8 & 0.794 & 3.053 & 66.654 & & & & & & \\
\hline 9 & 0.769 & 2.958 & 69.612 & & & & & & \\
\hline 10 & 0.741 & 2.852 & 72.464 & & & & & & \\
\hline 11 & 0.647 & 2.489 & 74.952 & & & & & & \\
\hline 12 & 0.628 & 2.416 & 77.369 & & & & & & \\
\hline 13 & 0.613 & 2.357 & 79.725 & & & & & & \\
\hline 14 & 0.605 & 2.328 & 82.053 & & & & & & \\
\hline 15 & 0.564 & 2.168 & 84.221 & & & & & & \\
\hline 16 & 0.518 & 1.992 & 86.214 & & & & & & \\
\hline 17 & 0.474 & 1.823 & 88.037 & & & & & & \\
\hline
\end{tabular}


Towards Excellence: An Indexed, Refereed \& Peer Reviewed Journal of Higher Education /

Dr. Bharat Kumar Lakra / Page 196-213

\begin{tabular}{|l|l|l|l|l|l|l|l|l|l|}
\hline 18 & 0.461 & 1.773 & 89.810 & & & & & & \\
\hline 19 & 0.442 & 1.701 & 91.511 & & & & & & \\
\hline 20 & 0.399 & 1.534 & 93.045 & & & & & & \\
\hline 21 & 0.379 & 1.457 & 94.502 & & & & & & \\
\hline 22 & 0.340 & 1.308 & 95.810 & & & & & & \\
\hline 23 & 0.319 & 1.225 & 97.035 & & & & & & \\
\hline 24 & 0.296 & 1.140 & 98.175 & & & & & & \\
\hline 25 & 0.264 & 1.016 & 99.191 & & & & & & \\
\hline 26 & 0.210 & 0.809 & 100 & & & & & & \\
\hline
\end{tabular}

Table- 4 above shows that Principal component method was applied to determine the minimum number of factors that accounted for maximum Variance in the data regarding the student's views about online teaching. As the table shows, all the factors together explained $52.884 \%$ of the total Variance the responses towards the variables that describe the online teaching features.

\section{Extraction Method: Principal Component Analysis}

Varimax rotation was applied, and it was determined those factors which are uncorrelated with each other. The rotated component matrix is given in the table- 5 below:

Table-5: Rotated Component Analysis

\begin{tabular}{|c|l|c|c|c|c|}
\hline \multicolumn{5}{|c|}{ Rotated Component Matrix } \\
\hline Sr.No. & Items & \multicolumn{3}{|c|}{ Component } \\
\cline { 3 - 7 } & & $(1)$ & (2) & (3) & (4) \\
\hline 1 & $\begin{array}{l}\text { Online teaching facilitates my achievement of the } \\
\text { objectives of the course }\end{array}$ & 0.768 & 0.193 & 0.186 & 0.193 \\
\hline 2 & $\begin{array}{l}\text { The online learning system can improve teaching } \\
\text { \& learning process }\end{array}$ & 0.739 & 0.411 & 0.095 & 0.085 \\
\hline 3 & $\begin{array}{l}\text { Online feedback provided is useful for topic } \\
\text { understanding }\end{array}$ & 0.697 & 0.047 & 0.241 & 0.232 \\
\hline 4 & I find online learning classes are useful & & & & \\
\hline 5 & Web Chatting sessions are useful for clarity of the \\
subjects & 0.648 & 0.170 & 0.279 & 0.003 \\
\hline
\end{tabular}


Towards Excellence: An Indexed, Refereed \& Peer Reviewed Journal of Higher Education /

Dr. Bharat Kumar Lakra / Page 196-213

\begin{tabular}{|c|c|c|c|c|c|}
\hline 6 & $\begin{array}{l}\text { Using online learning is easier to complete my } \\
\text { tasks }\end{array}$ & 0.642 & 0.294 & 0.269 & 0.190 \\
\hline 7 & $\begin{array}{l}\text { The online learning system can improve my } \\
\text { academic performance }\end{array}$ & 0.626 & 0.438 & 0.106 & 0.099 \\
\hline 8 & $\begin{array}{l}\text { Web conferencing facilitates my achievement of } \\
\text { the course objectives }\end{array}$ & 0.604 & 0.290 & 0.341 & 0.129 \\
\hline 9 & Online material assists my learning & 0.573 & 0.185 & 0.309 & 0.289 \\
\hline 10 & I intend to do fully online class & 0.549 & 0.389 & -0.018 & 0.046 \\
\hline 11 & I think online classes are easier to follow & 0.254 & 0.751 & 0.081 & 0.099 \\
\hline 12 & $\begin{array}{l}\text { I think I would gain more knowledge in an online } \\
\text { class }\end{array}$ & 0.284 & 0.686 & 0.109 & 0.141 \\
\hline 13 & Online classes are easier & 0.275 & 0.669 & 0.222 & 0.145 \\
\hline 14 & I think online classes have easier assignments & 0.091 & 0.529 & 0.335 & 0.120 \\
\hline 15 & Online classes are easy to fit into my schedule & 0.252 & 0.492 & 0.055 & -0.035 \\
\hline 16 & I think I would understand more in the online class & 0.485 & 0.486 & -0.096 & 0.173 \\
\hline 17 & I think I would engage more in the online class & -0.031 & 0.480 & -0.089 & 0.263 \\
\hline 18 & Online learning is user-friendly & 0.303 & 0.424 & 0.059 & 0.203 \\
\hline 19 & I find the online learning system easy to use & 0.312 & 0.406 & 0.228 & 0.160 \\
\hline 20 & $\begin{array}{l}\text { The teacher provides useful comments on my tasks } \\
\text { by online }\end{array}$ & 0.270 & -0.007 & 0.767 & 0.090 \\
\hline 21 & $\begin{array}{l}\text { The teacher responds promptly to e-mails and other } \\
\text { communications }\end{array}$ & 0.219 & 0.126 & 0.729 & 0.143 \\
\hline 22 & $\begin{array}{l}\text { Online discussion facilitates my achievement of the } \\
\text { objectives of the course }\end{array}$ & 0.265 & 0.426 & 0.460 & -0.019 \\
\hline 23 & $\begin{array}{l}\text { Online classes offer more flexibility in terms of } \\
\text { deadlines }\end{array}$ & 0.052 & 0.211 & 0.280 & 0.693 \\
\hline 24 & $\begin{array}{l}\text { I think I could be participative more in-class } \\
\text { discussion in an online class }\end{array}$ & 0.233 & 0.090 & -0.056 & 0.637 \\
\hline 25 & $\begin{array}{l}\text { Online classes offer more flexibility in organizing } \\
\text { my study materials }\end{array}$ & 0.482 & 0.140 & 0.181 & 0.491 \\
\hline 26 & $\begin{array}{l}\text { Online classes offer more flexibility in managing } \\
\text { my study time }\end{array}$ & 0.316 & 0.327 & 0.160 & 0.402 \\
\hline
\end{tabular}


Towards Excellence: An Indexed, Refereed \& Peer Reviewed Journal of Higher Education /

\section{Dr. Bharat Kumar Lakra / Page 196-213}

Extraction Method: Principal Component Analysis. Rotation Method: Varimax with Kaiser Normalisation.

\section{Rotated converged in 8 iterations.}

The factor analysis resulted in a total of four (4) factors that describes the student's perceptions of online teaching. The factors named accordingly the variables that converged within them, which is shown in able-6 below:

Table-6: Factor Matrix

\begin{tabular}{|c|c|c|c|c|c|}
\hline Factor Name & Items & $\begin{array}{c}\text { Item } \\
\text { Loading }\end{array}$ & $\begin{array}{c}\text { Total } \\
\text { Factor } \\
\text { Loading }\end{array}$ & $\begin{array}{l}\text { Eigen } \\
\text { Value }\end{array}$ & $\begin{array}{c}\text { \% of } \\
\text { VariVariance }\end{array}$ \\
\hline \multirow{7}{*}{$\begin{array}{c}\text { (1) } \\
\text { Perceived } \\
\text { Usefulness }\end{array}$} & & & 6.541 & 5.623 & 21.626 \\
\hline & $\begin{array}{l}\text { Online teaching } \\
\text { facilitates my } \\
\text { achievement of the } \\
\text { objectives of the course }\end{array}$ & 0.768 & & & \\
\hline & $\begin{array}{l}\text { The online learning } \\
\text { system can improve } \\
\text { teaching \& learning } \\
\text { process }\end{array}$ & 0.739 & & & \\
\hline & $\begin{array}{l}\text { Online feedback provided } \\
\text { is useful for topic } \\
\text { understanding }\end{array}$ & 0.697 & & & \\
\hline & $\begin{array}{l}\text { I find online learning } \\
\text { classes are useful }\end{array}$ & 0.695 & & & \\
\hline & $\begin{array}{l}\text { Web Chatting sessions } \\
\text { are useful for clarity of } \\
\text { the subjects }\end{array}$ & 0.648 & & & \\
\hline & $\begin{array}{l}\text { Using online learning is } \\
\text { easier to complete my } \\
\text { tasks }\end{array}$ & 0.642 & & & \\
\hline
\end{tabular}


Towards Excellence: An Indexed, Refereed \& Peer Reviewed Journal of Higher Education / Dr. Bharat Kumar Lakra / Page 196-213

\begin{tabular}{|c|c|c|c|c|c|}
\hline & $\begin{array}{l}\text { The online learning } \\
\text { system can improve my } \\
\text { academic performance }\end{array}$ & 0.626 & & & \\
\hline & $\begin{array}{l}\text { Web conferencing } \\
\text { facilitates my } \\
\text { achievement of the } \\
\text { course objectives }\end{array}$ & 0.604 & & & \\
\hline & $\begin{array}{l}\text { Online material assists } \\
\text { my learning }\end{array}$ & 0.573 & & & \\
\hline & $\begin{array}{l}\text { I intend to do fully online } \\
\text { class }\end{array}$ & 0.549 & & & \\
\hline \multirow{11}{*}{$\begin{array}{c}\text { (2) } \\
\text { Students } \\
\text { Supportiveness }\end{array}$} & & & 4.923 & 4.043 & 15.55 \\
\hline & $\begin{array}{l}\text { I think online classes are } \\
\text { more comfortable to } \\
\text { follow }\end{array}$ & 0.751 & & & \\
\hline & $\begin{array}{l}\text { I think I would gain more } \\
\text { knowledge in an online } \\
\text { class }\end{array}$ & 0.686 & & & \\
\hline & Online classes are easier & 0.669 & & & \\
\hline & $\begin{array}{l}\text { I think online classes } \\
\text { have easier assignments }\end{array}$ & 0.529 & & & \\
\hline & $\begin{array}{l}\text { Online classes are easy to } \\
\text { fit into my schedule }\end{array}$ & 0.492 & & & \\
\hline & $\begin{array}{l}\text { I think I would } \\
\text { understand more in the } \\
\text { online class }\end{array}$ & 0.486 & & & \\
\hline & $\begin{array}{l}\text { I think I would more } \\
\text { engage in the online class }\end{array}$ & 0.480 & & & \\
\hline & $\begin{array}{l}\text { Online learning is user- } \\
\text { friendly }\end{array}$ & 0.424 & & & \\
\hline & $\begin{array}{l}\text { I find the online learning } \\
\text { system easy to use }\end{array}$ & 0.406 & & & \\
\hline & & & 1.956 & 2.242 & 8.624 \\
\hline
\end{tabular}


Towards Excellence: An Indexed, Refereed \& Peer Reviewed Journal of Higher Education / Dr. Bharat Kumar Lakra / Page 196-213

\begin{tabular}{|c|c|c|c|c|c|}
\hline \multirow{3}{*}{$\begin{array}{c}\text { (3) } \\
\text { Faculty } \\
\text { Responsiveness }\end{array}$} & $\begin{array}{l}\text { The teacher provides } \\
\text { useful comments on my } \\
\text { tasks by online }\end{array}$ & 0.767 & & & \\
\hline & $\begin{array}{l}\text { The teacher responds } \\
\text { promptly to e-mails and } \\
\text { other communications }\end{array}$ & 0.729 & & & \\
\hline & $\begin{array}{l}\text { Online discussion } \\
\text { facilitates my } \\
\text { achievement of the } \\
\text { objectives of the course }\end{array}$ & 0.460 & & & \\
\hline \multirow{6}{*}{$\begin{array}{l}\quad(4) \\
\text { Perceived } \\
\text { Flexibility }\end{array}$} & & & 2.358 & 1.842 & 7.085 \\
\hline & $\begin{array}{l}\text { Online classes offer more } \\
\text { flexibility in terms of } \\
\text { deadlines }\end{array}$ & 0.767 & & & \\
\hline & $\begin{array}{l}\text { I think I could be } \\
\text { participative more in- } \\
\text { class discussion in an } \\
\text { online class }\end{array}$ & 0.729 & & & \\
\hline & $\begin{array}{l}\text { Online classes offer more } \\
\text { flexibility in organizing } \\
\text { my study materials }\end{array}$ & 0.460 & & & \\
\hline & $\begin{array}{l}\text { Online classes offer } \\
\text { more flexibility in } \\
\text { managing my study time }\end{array}$ & 0.402 & & & \\
\hline & Total & & 15.887 & 13.57 & 52.884 \\
\hline
\end{tabular}

\section{Factors affecting Students Perception's regarding Online Teaching Characteristics}

The table- 6 above shows the four factors that affect the students' views about online teaching characteristics along with the percentage of Variance by each factor that indicates their relative importance in terms of perceptions about online teaching characteristics instruction seen that student perceptions about online teaching are positively affected by "Perceived Usefulness" of online teaching. The second most important factor is student supportiveness, followed by faculty responsiveness and perceived flexibility. Online teaching 
establishing the relationship between students' perceptions regarding the online teaching characteristics and overall satisfaction levels of online teaching.

Further, Multiple Regression Analysis has been analyzed to inspect the relationship between the various online teaching features and the overall satisfaction from online teaching, which is given in table-7 below:

Table-7: Multiple Regression Analysis

\begin{tabular}{|c|c|c|c|c|c|}
\hline \multirow{3}{*}{ Model } & \multicolumn{3}{|c|}{ Coefficients } & \multirow{3}{*}{$\mathbf{t}$} & \multirow{3}{*}{ Sig. } \\
\hline & \multicolumn{2}{|c|}{$\begin{array}{c}\text { Unstandardized } \\
\text { Coefficients }\end{array}$} & \multirow{2}{*}{$\begin{array}{c}\begin{array}{c}\text { Standardized } \\
\text { Coefficients }\end{array} \\
\text { Beta }\end{array}$} & & \\
\hline & $\mathbf{B}$ & Std. Error & & & \\
\hline (Constant) & -0.999 & 0.329 & & -3.035 & 0.003 \\
\hline Perceived Usefulness & 0.581 & 0.110 & 0.392 & 5.299 & 0.000 \\
\hline Students Supportiveness & 0.278 & 0.116 & 0.160 & 2.397 & 0.017 \\
\hline Faculty Responsiveness & 0.216 & 0.086 & 0.137 & 2.506 & 0.013 \\
\hline Perceived Flexibility & 0.154 & 0.068 & 0.132 & 2.256 & 0.025 \\
\hline \multicolumn{6}{|c|}{ Note: $\mathrm{R}^{2}=.498 ;$ Adjusted $\mathrm{R}^{2}=4.90 ; \mathrm{F}$ Value $=64.690 ;$ Sig. $=.000$} \\
\hline \multicolumn{6}{|c|}{ Dependent Variable: Overall Satisfaction } \\
\hline
\end{tabular}

Predictors: Perceived Usefulness, Students Supportive, Faculty Responsiveness, Perceived Flexibility

Dependent Variable: Overall Satisfaction

The above table shows that the estimated regression model can be presented as:

Overall Satisfaction $=\mathbf{- 0 . 9 9 9}+\mathbf{0 . 5 8 1} *$ Perceived Usefulness $+\mathbf{0 . 2 7 8} *$ Students Supportiveness +0.216 * Faculty Responsiveness + 0.154 * Perceived Flexibility.

Thus, "perceived usefulness" is the main factor in the overall satisfaction level in online teaching. $\mathrm{R}$ squared is the proportion of variation in the dependent variable explained by the regression model. From the above table-7, $\mathrm{R}$ squared value is 4.98 , which is a moderate relationship between the extracted factor scores and overall satisfaction of online teaching, which suggests that several other factors which affects the online teaching. This may be deal with the other factors such as online teaching environment, teacher students' relationships, course structure, communication and presentation; maybe more contributing factors to their overall satisfaction relatively than the above-stated factors. 


\section{Discussion}

The study findings support the previous studies that document particular teaching practices rated highly by the students in online teaching. These can be summarized as concern for students, instructor flexibility, teacher responsiveness with regards to students' feedback (Dennen et al.,2007; Fabry,2012; Jackson et al., 2010), all practices that would be included within the element of teaching presence in the community of inquiry model of online learning (Garrison et al., 2000). The findings from this study begin to expand the understanding of different aspects of online pedagogy, particularly among the university students.

\section{Implications of the Study}

This study is useful for the faculty and educators of online teaching. They can understand the student's perceptions regarding the online characteristics that student value most, the factors they consider for their online learning decision. Educational institutions and faculty can formulate their pedagogical strategies according to the student's perceptions to attract more and more online teaching and learning process. Teachers may construct proper pedagogical techniques which can be suitable for accessing, understanding and application of online teaching-learning. This study has also added value for further research utilizing assessment of students learning styles and their effect on student learning in the online courses.

\section{Conclusion}

Based on the findings of this study can be concluded that the overall perceptions of the students regarding online teaching had a positive perception among the students. The result states that perceived usefulness, student supportiveness, faculty responsiveness and perceived flexibility have an effect on student perceptions and the overall satisfaction about the online teaching. Perceived usefulness is the most important factor that attracts student towards learning through online mode, and the same factor is also major contributing factors to the overall satisfaction level of online teaching. The findings of this research generally related to previous studies investigating the perceptions of students with regard to the online course (Seok,2010; Capra,2011; Fabry,2012). In future, similar studies can also be undertaken in different regions, states and nations or comparative studies may be undertaken. 


\section{References}

1. Capra, Theresa. "Online education: Promise and problems." Journal of Online Learning and Teaching 7.2 (2011): 288-293.

2. Sammons, Morris. "Exploring the new conception of teaching and learning in distance education." Handbook of distance education (2003): 387-397.

3. Keeton, Morris T. "Best online instructional practices: Report of phase I of an ongoing study." Journal of Asynchronous Learning Networks 8.2 (2004): 75-100.

4. Cuthrell, Kristen, and Anna Lyon. "Instructional strategies: What do online students prefer." MERLOT Journal of Online Learning and Teaching 3.4 (2007): 357-362.

5. Dixson, Marcia D. "Creating effective student engagement in online courses: What do students find engaging?" Journal of the Scholarship of Teaching and Learning (2010): $1-13$.

6. Brinthaupt, Thomas M., et al. "What the best online teachers should do." MERLOT Journal of Online Learning and Teaching 7.4 (2011):515-524.

7. Keeton, Morris T. "Best online instructional practices: Report of phase I of an ongoing study." Journal of Asynchronous Learning Networks 8.2 (2004): 75-100.

8. Allen, I. Elaine, and Jeff Seaman. Changing course: Ten years of tracking online education in the United States. Sloan Consortium. PO Box 1238, Newburyport, MA 01950, 2013.

9. Moise, Gabriela. "Fuzzy enhancement of creativity in collaborative online learning." International Conference on Web-Based Learning. Springer, Berlin, Heidelberg, 2012.

10. Kim, Kyong-Jee, and Curtis J. Bonk. "The future of online teaching and learning in higher education." Educause Quarterly 29.4 (2006): 22-30.

11. Hutton, Susan. "Course Design Strategies--Traditional versus On-line. What Transfers? What Doesn't?" (1999).

12. Salas-Morera, Lorenzo, Antonio Arauzo-Azofra, and Laura García-Hernández. "Analysis of online quizzes as a teaching and assessment tool." Journal of Technology and Science Education 2.1 (2012): 39-45.

13. Kearns, Lorna R. "Student assessment in online learning: Challenges and effective practices." Journal of Online Learning and Teaching 8.3 (2012): 198.

14. Ruth, Derek, and Susan E. Conners. "Distance learning in a core business class: Determinants of success in learning outcomes and post-course performance." Academy of Educational Leadership Journal 16.1 (2012): 123. 
Towards Excellence: An Indexed, Refereed \& Peer Reviewed Journal of Higher Education /

Dr. Bharat Kumar Lakra / Page 196-213

15. Carlson, Julie, and Deborah Jesseman. "Have we asked them yet? Graduate student preferences for web-enhanced learning." Quarterly Review of Distance Education 12.2 (2011): 125.

16. Morris, Libby V., and Catherine L. Finnegan. "Best practices in predicting and encouraging student persistence and achievement online." Journal of College Student Retention: Research, Theory \& Practice 10.1 (2008): 55-64.

17. Perry, Edward H., and Michelle L. Pilati. "Online learning." New Directions for Teaching and Learning 128 (2011): 95-104.

18. Rasheed, Rasheed Abubakar, Amirrudin Kamsin, and Nor Aniza Abdullah. "Challenges in the online component of blended learning: A systematic review." Computers \& Education 144 (2020): 103701.

19. Smith, Karen, and John Hill. "Defining the nature of blended learning through its depiction in current research." Higher Education Research \& Development 38.2 (2019): 383-397.

20. Dennen, Vanessa P., A. Aubteen Darabi, and Linda J. Smith. "Instructor-learner interaction in online courses: The relative perceived importance of particular instructor actions on performance and satisfaction." Distance education 28.1 (2007): 65-79.

21. Fabry, Dee L. "Using student online course evaluations to inform pedagogy." Journal of Research in Innovative Teaching 5.1 (2012): 45-52.

22. Jackson, Lana C., Stephanie J. Jones, and Roy C. Rodriguez. "Faculty actions that result in student satisfaction in online courses." Journal of Asynchronous Learning Networks 14.4 (2010): 78-96.

23. Garrison, D. Randy, Terry Anderson, and Walter Archer. "A theory of critical inquiry in online distance education." Handbook of distance education 1 (2003): 113-127.

24. Seok, Soonhwa, et al. "Comparison of Instructors' and Students' Perceptions of the Effectiveness of Online Courses." Quarterly Review of Distance Education 11.1 (2010): 25 .

\section{Dr Bharat Kumar Lakra Assistant Professor (Stage-II)}

\section{Department of Industrial Relations \& Personnel Management Berhampur University, Odisha.e-mail: bk.lakra99@gmail.com}

